\title{
Corrigendum: Dock8 mutations cripple B cell immunological synapses, germinal centers and long-lived antibody production
}

Katrina L Randall, Teresa Lambe, Andy Johnson, Bebhinn Treanor, Edyta Kucharska, Heather Domaschenz, Belinda Whittle, Lina E Tze, Anselm Enders, Tanya L Crockford, Tiphaine Bouriez-Jones, Duncan Alston, Jason G Cyster, Michael J Lenardo, Fabienne Mackay, Elissa K Deenick, Stuart G Tangye, Tyani D Chan, Tahra Camidge, Robert Brink, Carola G Vinuesa, Facundo D Batista, Richard J Cornall \& Christopher C Goodnow

Nat. Immunol. 10, 1283-1291 (2009); published online 8 November 2009; corrected after print 4 December 2009

In the version of this article initially published, the third author's name is missing the middle initial. The correct name is Andy L Johnson. The error has been corrected in the HTML and PDF versions of the article.

\section{Erratum: An essential role for the transcription factor HEB in thymocyte survival, Tcra rearrangement and the development of natural killer T cells}

Louise M D’Cruz, Jamie Knell, Jessica K Fujimoto \& Ananda W Goldrath

Nat. Immunol. 11, 240-249 (2010); published online 14 February 2010; corrected after print 12 March 2010

In the version of this article initially published, references $35-41$ were cited out of order in the text. The citations on page 247 should be as follows: column one, first paragraph, second full sentence, "RAG- 2 recombinase protein ${ }^{35,36}$, which could in turn impair rearrangements ${ }^{37 " ;}$ column two, middle paragraph, final two sentences, "iNKT development ${ }^{20-23,28,29,38,39}$....from stage 0 through stage 2 (refs. 20,38)"; column two, final paragraph,

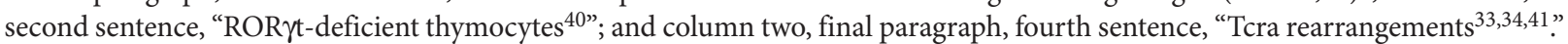
The reference list should be as follows:

37. Yannoutsos, N. et al. The role of recombination activating gene (RAG) reinduction in thymocyte development in vivo. J. Exp. Med. 194, 471-480 (2001).

38. Nichols, K.E. et al. Regulation of NKT cell development by SAP, the protein defective in XLP. Nat. Med. 11, 340-345 (2005).

39. Savage, A.K. et al. The transcription factor PLZF directs the effector program of the NKT cell lineage. Immunity 29, 391-403 (2008).

40. Benlagha, K., Wei, D.G., Veiga, J., Teyton, L. \& Bendelac, A. Characterization of the early stages of thymic NKT cell development. J. Exp. Med. 202, 485-492 (2005).

41. Sun, Z. et al. Requirement for ROR y in thymocyte survival and lymphoid organ development. Science 288, 2369-2373 (2000).

The error has been corrected in the HTML and PDF versions of the article.

\section{Erratum: Temporal changes in dendritic cell subsets, cross-priming and costimulation via CD70 control CD8+ T cell responses to influenza}

André Ballesteros-Tato, Beatriz León, Frances E Lund \& Troy D Randall

Nat. Immunol. 11, 216-224 (2010); published online 24 January 2010; corrected after print 7 May 2010

In the version of this article initially published, the label along the vertical axis of Figure $6 \mathrm{~h}$ was incorrect. The correct label is "OT-II proliferating cells $\left(\times 10^{2}\right)$." The error has been corrected in the HTML and PDF versions of the article. 